Acta Technologica Agriculturae 1

Nitra, Slovaca Universitas Agriculturae Nitriae, 2021, pp. 8-13

\title{
ORGANIC WASTE CONVERSION VIA CONTINUOUS ANAEROBIC CO-DIGESTION OF OIL PALM EMPTY FRUIT BUNCHES AND COW MANURE: EVALUATION OF FEEDING REGIME ON METHANE PRODUCTION
}

\author{
DARWIN*, Atmadian PRATAMA, MARDHOTILLAH \\ Syiah Kuala University, Banda Aceh, Indonesia
}

\begin{abstract}
Anaerobic co-digestion of oil palm empty fruit bunches with cow manure was studied. The research focus was on the evaluation of feeding different solid concentrations of the substrate in the on-going process of anaerobic digestion. The solid concentrations ranged from 0.5 to $12 \%$ TS. Results of the study showed that the maximum methane production could be reached with the reactor digesting substrates with 4 to $8 \%$ TS, in which the methane produced was from 1300 to $1400 \mathrm{~mL}$ per day. A significant drop of $\mathrm{pH}$ from 7.02 to 5.97 occurred when the reactor was digesting substrates with 10 and $12 \%$ TS. Acidic condition caused by organic matter overloads lowered the efficiency of organic conversion represented in the low removal of COD, which was only $22.4 \%$. This finding is highly significant for the waste management industries in terms of dealing with the digester upset due to the digestion of large amount of organic wastes.
\end{abstract}

Keywords: solid concentration; methane inhibition; acid accumulation

The oil palm (Elaeis guineensis) is the main crop in Indonesia. As a vital industry for supporting the economy, the oil palm trees have been massively cultivated in many parts of Indonesia's islands, such as Sumatera, Kalimantan and Sulawesi. The extraction of oil palm fruits and kernel generates a valuable vegetable oil. Currently, the vegetable oil produced from the oil palm has dominated the world vegetable oil market (USDA, 2007; Nieves et al., 2011). A third of the world vegetable oil consumption has been derived from the palm oil and is expected to increase within the next 20 to 30 years (Corley, 2009; Walter et al., 2009).

During the oil manufacturing process, large amounts of lignocellulosic wastes, such as empty fruit bunches, mesocarp fibres and shells, are generated. The wastes are periodically produced when palm oil and kernel oil are extracted from the pulp (endocarp) of oil palm fruits (Walter et al., 2009). Oil palm empty fruit bunch is the major lignocellulosic waste in the oil palm industry, which is commonly burned and/ or incinerated, what can pollute the environment around the palm oil industry areas. As a non-wood lignocellulosic biomass, oil palm empty fruit bunch can potentially be used as a feedstock for bio-energy production (i.e. biogas). Biogas is a renewable energy produced biologically via anaerobic digestion process. Typical feedstock that can be used for biogas production includes energy crops and waste materials, such as wastewater, animal manure and agricultural wastes (Rahimi-Ajdadi and Esmaili, 2020). The major component of biogas is methane, which is clean and flammable gas containing high calorific value (55 MJ.kg-1) (Dinçer and Zamfirescu, 2014), and thereby can potentially be used as a gaseous biofuel for power generation (AguilarVirgen et al., 2014; Uddin et al., 2016).

As the palm oil manufacturer would continuously generate large amounts of organic wastes, managing the wastes properly is crucial for protecting the environment from the pollution and sustaining the operation of palm oil industry as a vital industry. The application of anaerobic digestion (AD) technology for treating the organic wastes from the palm oil industry is feasible, because the AD can effectively decompose the organic wastes and generate valuable gas (i.e. methane) from the energy-rich by-products (Nasir et al., 2012). Several studies (Aslanzadeh et al., 2014; Darwin et al., 2019) dealing with the operational systems and reactor design for running the process of anaerobic digestion have been carried out. Selection of a system for operating the AD highly depends on the existing reactor infrastructures. The types of biodegradable feedstock and their availability in a sufficient amount are important factors to be considered prior to establishing the process of anaerobic digestion on a small and/or large scale (Bacenetti et al., 2013; Naik et al., 2014; Liu et al., 2015). The study presented aims to evaluate the methane production in anaerobic co-digestion of oil palm empty fruit bunches with cow manure, and to investigate the effects of solid content in the continuous process of $A D$ towards the daily methane production. The effectiveness of $A D$ process is also investigated through the assessment of methane yield, productivity and the organic removal.

Contact address: DARWIN, Syiah Kuala University, Department of Agricultural Engineering, Banda Aceh 23111, Indonesia, e-mail: darwin_ae@unsyiah.ac.id 


\section{Material and methods}

\section{Material preparation}

Oil palm empty fruit bunches used for this research were obtained from a palm oil mill in PPKS Bukit Sentang, Babalan-District of Langkat, North Sumatera. The collected feedstock was ground using a laboratory grinder to an average particle size of $1 \pm 0.2 \mathrm{~mm}$. Cow manure utilized for the experiment was taken from the farm at Limpok, Darussalam, Banda Aceh, Indonesia. The manure was screened to remove any contaminants (e.g. sands, gravels, woods, metals and plastics), and stored in the fridge at the temperature of $4-5^{\circ} \mathrm{C}$ prior to using it.

\section{Experimental design and procedures}

Experiments of AD process were conducted at the Laboratory of Post-Harvest Technology and Bioprocess, Department of Agricultural Engineering, Syiah Kuala University. Several sample analysis measurements were carried out at the Institute for Research and Standardization of Industry, Banda Aceh. Two identical bioreactors made of acrylic were used for operating the AD process. The two reactors were continuously stirred at $100 \mathrm{rpm}$. The first reactor operated the process of anaerobic co-digestion of oil palm empty fruit bunches with cow manure, while the second reactor performed as the control reactor operating the $A D$ of cow manure only. Both reactors ran under the steady state condition, in which the operational temperature was maintained under the mesophilic condition of $35 \pm 1{ }^{\circ} \mathrm{C}$ by using thermostatic water bath.

The working volume of the reactor was $4000 \mathrm{ml}$. The hydraulic retention time (HRT) applied for this experiment was 25 days. The loading rate applied for this experiment was $160 \mathrm{~mL} /$ day. To accomplish continuous operation, each reactor was equipped with the influent and effluent sample ports on the top of the reactors. To evaluate the performance of digesters, samples of the effluent from each reactor were withdrawn daily for further analysis. In order to ensure the process of anaerobic digestion under the continuous operation working properly, $\mathrm{pH}$ of the samples including influent as well as effluent was monitored periodically during the feeding and decanting periods. As $\mathrm{pH}$ was not controlled during the process, no alkaline and acid was added to the digesters. Methane production was measured daily using a gas meter based on the water displacement method.

Five hundred $\mathrm{ml}$ of $4 \mathrm{Molar} \mathrm{NaOH}$ was filled in a filter flask, which was then connected to the gas meters and reactors to purify the gas produced from the digester, and to entrap the contaminant gases (i.e. $\mathrm{CO}_{2}, \mathrm{H}_{2} \mathrm{~S}$ ). Prior to the experiment start, the culture was acclimated under the anoxic and mesophilic conditions until reaching the steady state condition with $\mathrm{pH}$ ranging between 6.8 and 7.2 (Darwin et al., 2018a). During the acclimation process, there were no substrates, alkaline and/or acid solutions added, and no effluent discarded.

\section{Investigation of feeding characters in anaerobic co-digestion}

Effects of changing the substrate solid concentration fed into the on-going anaerobic co-digestion of oil palm empty fruit bunches (OPEFB) and cow manure were investigated via chemostat tests or continuous operating digesters. The reactors were operated within two cycles of HRT, i.e. 50 days. Firstly, $0.5 \%$ TS of the ground oil palm empty fruit bunch was added to the anaerobic co-digestion reactor, and the culture was acclimatized under the anaerobic condition for 10 days. During the acclimatization process, the culture in reactor was neither fed nor discharged.

Tests of the effects of different solid concentrations on the on-going process of anaerobic co-digestion of the OPEFB and cow manure were carried out after 10-day digestion, in which the reactor was fed with $0.5 \%$ TS of the ground OPEFB for 5 days since day 11 . Since day 15 , the reactor was fed with $1 \%$ TS of the ground OPEFB for 5 days. From day 20 to day 25, the reactor was fed with $2 \%$ TS of the ground OPEFB. From day 25 to day 30, the reactor was fed with $4 \%$ TS of the ground OPEFB. From day 30 to day 35, the reactor was fed with $8 \%$ TS of the ground OPEFB. From day 35 to day 40, the reactor was fed with $10 \%$ TS of the ground OPEFB. From day 40 to day 50 and/or the rest of experimental time, the reactor was fed with $12 \%$ TS of the ground OPEFB. During the process, $\mathrm{pH}$ was not adjusted and/or controlled.

\section{Analytical methods}

The samples of influent and effluent were analysed for total solids (TS), volatile solids (VS), total dissolved solids (TDS), moisture content $(\mathrm{MC}), \mathrm{pH}$, chemical oxygen demand (COD), alkalinity, total Kjeldahl nitrogen (TKN). All analysed parameters were measured according to the Standard Method (Rice et al., 2017). In order to evaluate the presence of organic components in the culture and their utilization, the analysis of solid content and its removal was measured. To evaluate the efficiency of biodegradation during the process of anaerobic digestion, the percentage of volatile solid reduction and COD removal was assessed. The rates of methane production were measured as the volume of methane produced per day. To evaluate the effectiveness of substrate utilization with the production of methane as the end-product, methane yield was determined as the total methane produced per gram of volatile solids added (Gontupil et al., 2012; Darwin et al., 2016).

\section{Results and discussion}

In order to evaluate the methane potential of OPEFB co-digested with cow manure, two identical anaerobic stirred reactors were utilized. The process of anaerobic digestion was operated in continuous mode to evaluate whether the addition of fresh substrates and effluent discharged could optimize the methane productivity and minimize the risk of digester failure. The physicochemical characteristics of the input materials used for anaerobic digestion were shown in Table 1.

Results show that the anaerobic culture of cow manure only possessed low $\mathrm{pH}$ of 6.02 , which was too acidic for 
AD. Hence, anaerobic co-digestion of OPEFB with cow manure could potentially stabilize the process of $A D$, as its alkalinity is higher $\left(3941 \mathrm{mg} \cdot \cdot^{-1}\right)$ than it would be in the AD of only cow manure as a single substrate $\left(2605 \mathrm{mg} \cdot \mathrm{l}^{-1}\right)$. The experiment results showed that the digestion of solely cow manure would have approx. four times lower organic loading rates $\left(0.31 \mathrm{~g} \cdot \mathrm{VS} \cdot \mathrm{I}^{-1} \cdot\right.$ day $\left.^{-1}\right)$ compared to the reactor processing the OPEFB co-digested with cow manure, which had a significant amount of organic matters loaded into the reactor $\left(1.4 \mathrm{~g} \cdot \mathrm{VS} \cdot \mathrm{I}^{-1} \cdot\right.$ day $\left.^{-1}\right)$.

Results show that, within initial 10 days of incubation, anaerobic co-digestion of the OPEFB and cow manure did not produce any significant amount of methane. In this period, the culture was in the lag phase, in which the microbial culture acclimatized to the anaerobic condition. During the acclimatization process, the anaerobic co-digestion reactor produced small amount of methane that was between 50 and $90 \mathrm{ml}$ per day, while no methane was produced in the control reactor (Fig. 1). Started at day 11 of incubation, chemostat test had been applied, in which $0.5 \%$ TS of the substrate was loaded into the anaerobic co-digestion reactor. From day 11 to day 15 , methane production increased from 50 to $630 \mathrm{ml}$ in the anaerobic co-digestion reactor. A dramatical increase of methane production occurred from day $15(630 \mathrm{ml})$ to day $20(1320 \mathrm{ml})$. This suggests that the sufficient amount of organic matters loaded into the digestion system can significantly enhance the methane production.

The result is quite different from the previous study revealing that $2 \%$ TS of the substrate fed to the digester could generate more methane yield compared to the digester fed with 3 and 4\% TS (Darwin et al., 2016). The differences found

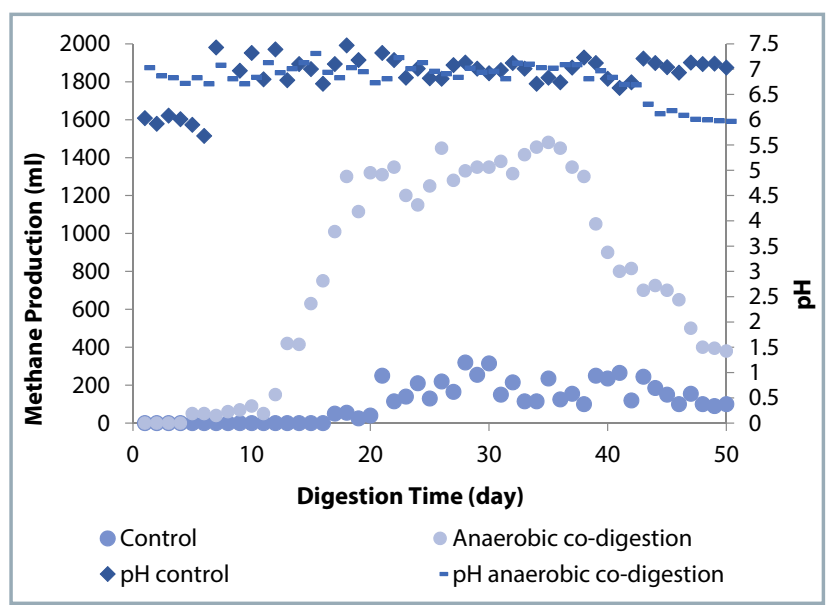

Fig. 1 Daily methane production of anaerobic co-digestion of oil palm empty fruit bunches and cow manure under the continuous operation

can be attributed to the different operational system and different types of substrate used for the experiments. The current study was operated in the continuous system and $1 \%$ TS was applied from day 15 to day 20 of the incubation period and, within that period, the methane yield obtained was approx. $176.33 \mathrm{ml} \mathrm{CH} \cdot \mathrm{g}^{-1} \cdot \mathrm{VS}^{-1}$, while the previous study was performed in the batch mode and generated the methane yield of $60.25 \mathrm{ml} \mathrm{CH} \mathrm{CH}_{4} \cdot \mathrm{g}^{-1} \cdot \mathrm{VS}^{-1}$ added after 35 days of fermentation. Furthermore, the substrates used in the previous study were swine manure co-digested with cocoa husk, while the present study deals with cow manure co-digested with the OPEFB.

Table 1 Characteristics of the substrates

\begin{tabular}{|l||c|c|c|}
\hline Parameters & Unit & Cow manure & Oil palm empty fruit bunches \\
\hline \hline Total solids & $\%$ & 0.988 & 18.764 \\
\hline Volatile solids & $\%$ & 47 & 70 \\
\hline Moisture content & $\%$ & 99.01 & 81.24 \\
\hline Total Kjeldahl nitrogen & $\mathrm{mg} \cdot \cdot^{-1}$ & 410 & - \\
\hline Chemical oxygen demand & $\mathrm{mg} \cdot{ }^{-1}$ & 9120 & - \\
\hline Alkalinity & $\mathrm{mg} \cdot{ }^{-1}$ & 2600 & - \\
\hline Total dissolved solids & $\mathrm{mg} \cdot{ }^{-1}$ & 2710 & - \\
\hline pH & - & 6.02 & - \\
\hline
\end{tabular}

Table 2 Influent data of anaerobic digestion process

\begin{tabular}{|l||c|c|c|}
\hline Parameters & Unit & Control (cow manure) & Oil palm empty fruit bunches co-digested with cow manure \\
\hline Total solids & $\%$ & 2.253 & 5.96 \\
\hline Volatile solids & $\%$ & 46.92 & 78.5 \\
\hline Moisture content & $\%$ & 97.75 & 94.04 \\
\hline Total Kjeldahl nitrogen & $\mathrm{mg} \cdot \cdot^{-1}$ & 414 & 435 \\
\hline Chemical oxygen demand & $\mathrm{mg} \cdot \cdot^{-1}$ & 9130 & 9874 \\
\hline Alkalinity & $\mathrm{mg} \cdot \mathrm{l}^{-1}$ & 2605 & 3941 \\
\hline Total dissolved solids & $\mathrm{mg} \cdot l^{-1}$ & 2730 & 4.25 \\
\hline Organic loading rate & $\mathrm{g} \cdot \mathrm{VS} \cdot \mathrm{l}^{-1} \cdot \mathrm{day}^{-1}$ & 0.317 & 1.402 \\
\hline pH & - & 6.08 & 7.03 \\
\hline
\end{tabular}


Results show that the methane production tended to decrease when the substrate concentration was increased from 8 to $10 \%$ TS. From day 36 of the incubation when the reactor was loaded with the substrate $10 \%$ TS, the daily methane production tended to decline. As depicted in Fig. 1 , from day 37 to 38 when the reactor was fed with 10\% TS of the substrate, the $\mathrm{pH}$ culture dropped from 7.09 to 6.81 . This condition continuously occurred until the rest of the experiment, in which the organic acids accumulated in the digester, and sharply dropped the $\mathrm{pH}$ to 5.9 on day 50 . This suggests that $10 \%$ TS of the substrate loaded to the reactor disturbed the AD process due to organic acid build-up, and thereby led to the digester upset, which totally prevented the methane production.

As presented in Table 3, the results show that effluent $\mathrm{pH}$ of the anaerobic co-digestion reactor ( $\mathrm{pH}$ 5.97) was lower than effluent $\mathrm{pH}$ of the control reactor (7.02). This occurred as an excessive amount of organic materials was loaded to the reactor (Fig. 1). The study also reveals that, at the early stage of the experiment, the organic loading rate introduced to the reactor was $1.402 \mathrm{~g} \cdot \mathrm{VS} \cdot \mathrm{I}^{-1} \cdot \mathrm{day}^{-1}$, which was approx. four times higher than the organic loading rate applied to the control reactor $\left(0.3 \mathrm{~g} \cdot \mathrm{VS} \cdot \mathrm{I}^{-1} \cdot \mathrm{day}^{-1}\right)$.

The assessment of biodegradation efficiency indicates that anaerobic co-digestion of the OPEFB with cow manure could significantly enhance the methane production in comparison to $A D$ of cow manure only. The results suggest that the methane productivity obtained from the anaerobic co-digestion reactor was approx. seven times higher $\left(795 \mathrm{ml} \mathrm{CH}_{4} \cdot\right.$ day $\left.^{-1}\right)$ than from the control reactor (109.9 $\mathrm{ml} \mathrm{CH}_{4} \cdot$ day $^{-1}$ ). Even if the gradual increase of the organic loads had been applied, the conversion of organic solid materials was still somewhat high, in which the volatile solids (VS) reduction obtained was at approx. $80 \%$. This is quite different from the study by Bujoczek et al. (2000), who reported that VS reduction would be low with an increase in organic acids and/or volatile fatty acids (VFA) in the digester. The difference occurred, as high percentage of VS reduction reported in Table 4 was obtained from the total organic solid reduction after 50 days of incubation.

The characteristics of substrates presented in Table 1 reveal that the OPEFB contained a lot of organic materials, representing $70 \%$ of volatile solids (VS). High percentage of VS indicates that the substrate contains a significant amount of organic matters (Darwin et al., 2016), which was required as a source of carbon and/or energy for the microbial growth and metabolism (Yu et al., 2015). This suggests that the OPEFB can be potential substrate used in AD to enhance the methane productivity.

The study shows that $\mathrm{pH}$ of cow manure was somewhat too acidic ( $\mathrm{pH}$ 6.02). The low $\mathrm{pH}$ can be an inhibitory factor when the single substrate is used as the only substrate for AD. Ye et al. (2012) mentioned that low pH can hinder methane production through direct inhibition of methanogenesis pathways and indirect effects on fermentation. The study reported that increasing $\mathrm{pH}$ enhances the efficiency of methane production, as well as fermentative activity, and increase the availability of substrates (i.e. acetate and/or $\mathrm{H} 2$ ) for methanogens, resulting in significant increase in methane productivity (Ye et al., 2012).

Lana et al. (1998) revealed that a drop of $\mathrm{pH}$ from 6.5 to 5.7 would significantly decrease the methane production. Authors found that low $\mathrm{pH}$ would dramatically lower buffering capacity in the culture. Since buffering capacity is essential to stabilize the AD process, enhancing buffering capacity in the culture is vital for improving the digestion performance (Zhu et al., 2010; Wang et al., 2014). The current study reveals that the OPEFB used as a co-substrate in AD of

Table 3 Effluent data of anaerobic digestion process

\begin{tabular}{|l||c|c|c|}
\hline Parameters & Unit & Control & Oil palm empty fruit bunches co-digested with cow manure \\
\hline \hline Total solids & $\%$ & 1.88 & 7.22 \\
\hline Volatile solids & $\%$ & 23.73 & 41.7 \\
\hline Moisture content & $\%$ & 98.12 & 92.8 \\
\hline Total Kjeldahl nitrogen & $\mathrm{mg} \cdot \cdot^{-1}$ & 390 & 417 \\
\hline Chemical oxygen demand & $\mathrm{mg} \cdot \cdot^{-1}$ & 7237 & 7661 \\
\hline Alkalinity & $\mathrm{mg} \cdot \cdot^{-1}$ & 2220 & 3210 \\
\hline Total dissolved solids & $\mathrm{mg} \cdot \cdot^{-1}$ & 2900 & 2.4 \\
\hline pH & & 7.02 & 5.97 \\
\hline
\end{tabular}

Table 4 Biodegradation efficiency of anaerobic digestion process operated in continuously stirred reactors

\begin{tabular}{|c|c|c|c|}
\hline Parameters & Unit & Control & $\begin{array}{l}\text { Oil palm empty fruit bunches co-digested } \\
\text { with cow manure }\end{array}$ \\
\hline COD removal & $\%$ & 20.73 & 22.41 \\
\hline Nitrogen removal & $\%$ & 5.80 & 4.14 \\
\hline Volatile solids reduction & $\%$ & 64.8 & 80.41 \\
\hline Total methane production & $\mathrm{ml}$ & 5495 & 39750 \\
\hline Methane productivity & $\mathrm{ml} \mathrm{CH}_{4} \cdot \mathrm{day}^{-1}$ & 109.9 & 795 \\
\hline Methane yield & $\mathrm{ml} \mathrm{CH}{ }_{4} \cdot \mathrm{g}^{-1} \cdot \mathrm{VS}^{-1}$ & 129.95 & 212.4 \\
\hline
\end{tabular}


cow manure can potentially enhance the buffering capacity, and thereby can significantly improve methane productivity.

The influent data shown in Table 2 reveal that the characteristics of the OPEFB co-digested with cow manure culture can be used to optimize the methane production. This is due to the fact that the $\mathrm{pH}$ culture was of the neutral level (7.03). Liu et al. (2008) mentioned that the appropriate $\mathrm{pH}$ level for methane production is from 6.6 to 7.8 with an optimum of 6.8. The digester failure would occur once $\mathrm{pH}$ in the digester was lower than 6.1 and/or higher than 8.3 (Liu et al., 2008).

The OPEFB co-digested with cow manure had a significant amount of organic materials represented by $80 \%$ VS, while the control reactor digesting cow manure only had volatile solid content less than $50 \%$. The organic content in substrates used for AD is significantly affected by the organic materials loaded into the reactor (Jiang et al., 2013; Darwin et al., 2017). This is significant, as the composition of the organic matters loaded to the digester would considerably affect the microbial growth rates, as well as the rates of methane production (Hallaji et al., 2019; Berberich et al., 2019).

The results suggest that, from day 11 to day 20, the anaerobic culture ran into an exponential or logarithmic phase, in which the production of methane increased significantly from 50 to $1350 \mathrm{ml}$. When the substrate concentration increased from 1\% TS (day 20) to 8\% TS (day 35), no significant increase in methane production was observed. The results indicate that, within the time of incubation from day 20 to day 35 , the anaerobic culture was in the stationary phase despite the fact that the substrate concentration was increased, and methane production fluctuated between 1350 and $1450 \mathrm{ml}$ (Fig. 1). This complies with findings of several authors (Kolter et al., 1992; Rallu et al., 1996; Heller, 2001), who revealed that microbes from the logarithmic phase would be much more susceptible to the environmental stresses in comparison to the microbes from the stationary phase.

The results also show that a lot of organic materials loaded into the anaerobic co-digestion reactor lowered the buffering capacity - the alkalinity dropped from 3941 to $3210 \mathrm{mg} \cdot \mathrm{l}^{-1}$. This condition led to a dramatic drop of $\mathrm{pH}$ due to the increase of proton concentration as a result of organic acids build-up. This agrees with the study by Xu et al. (2014): the high organic loads cause the excessive accumulation of organic acids, especially volatile fatty acids (VFA), and thereby can intensively inhibit the AD. The study found that acetic acid was the primary inhibitor for methanogenesis. With an increase in organic loads, acetoclastic methanogenesis would be more sensitive to acetic acid in comparison to hydrogenotrophic methanogenesis (Xu et al., 2014).

The evidence obtained from the anaerobic co-digestion reactor was that the total solids of effluent were higher (7.22\%) than total solids of influent $(5.96 \%)$, suggesting that the low $\mathrm{pH}$ caused by organic acids build-up can inhibit the conversion of the substrate loaded (Table 1 and 2). This agrees with several studies (Veeken et al., 2000; Darwin et al., 2018b) revealing that high concentration of VFA accompanied by low $\mathrm{pH}$ can inhibit hydrolysis and can completely inhibit fermentation process to certain extent.
Sincetheanaerobicco-digestion reactorranintosubstrate overloading that caused the organic acids accumulation, the decomposition process of organic materials to methane as the end-product was slowed down. The acidic condition had inhibited the growth of anaerobic microbes, as well as their activity, and thereby the conversion rates of all organic materials to methane gas were lowered. This phenomenon led to the low biodegradation efficiency, resulting in the COD removal from the anaerobic co-digestion reactor of approx. $22 \%$. This agrees with the study by Bujoczek et al. (2000), who observed that the efficiency of organic matter conversion decreased with the decreased feeding of organic loads to the digesters.

The result of COD removal suggests that the conversion of organic matters to methane had been hindered by the low $\mathrm{pH}(\mathrm{pH}<6.0)$. The study results also reveal that an overloading of substrate reduces the methane yield. This agrees with the study by Dai et al. (2013) showing that high organic loading rates applied to the anaerobic digester would potentially generate high risk of souring the culture, and thereby could inhibit the oxidation of organic materials to methane. As depicted in Table 4, the methane yield obtained from the anaerobic co-digestion reactor operated for 50 days of incubation was higher only by $39 \%$ than methane yield of the control reactor. This indicates that the anaerobic co-digestion of the OPEFB with cow manure should not be performed with solid concentrations lower than $8 \%$ TS in order to avoid organic acids accumulation in the digester that would suppress methanogens.

\section{Conclusion}

The current study results show that the addition of OPEFB as co-substrate in $A D$ of cow manure resulted in higher methane productivity ( $795 \mathrm{ml} \mathrm{CH}_{4} \cdot$ day $^{-1}$ ) in comparison to the digestion of cow manure only $\left(109.9 \mathrm{ml} \mathrm{CH}_{4}\right.$.day $\left.{ }^{-1}\right)$. The increase of organic loads by feeding the substrate with $10 \%$ TS into the anaerobic co-digestion reactor could gradually generate acids in the culture. A dramatic drop of $\mathrm{pH}$ due to acid accumulation in the digester led to the low efficiency of the organic matter conversion, in which the COD removal was less than thirty percent, and thereby the methane production was severely hindered.

\section{Acknowledgements}

We kindly thank Universitas Syiah Kuala, Banda Aceh, Indonesia for financial support through the $\mathrm{H}$-index research program coordinated by LPPM, UNSYIAH.

\section{References}

AGUILAR-VIRGEN, Q. - TABOADA-GONZÁLEZ, P. - OJEDA-BENÍTEZ, S. CRUZ-SOTELO, S. 2014. Power generation with biogas from municipal solid waste: Prediction of gas generation with in situ parameters. In Renewable and Sustainable Energy Reviews, vol. 30, pp. 412-419.

ASLANZADEH, S. - RAJENDRAN, K. - TAHERZADEH, M. J. 2014. A comparative study between single-and two-stage anaerobic digestion processes: Effects of organic loading rate and hydraulic retention time. In International Biodeterioration and Biodegradation, vol. 95, pp. 181-188.

BACENETTI, J. - NEGRI, M. - FIALA, M. - GONZÁLEZ-GARCÍA, S. 2013. Anaerobic digestion of different feedstocks: impact on energetic 
and environmental balances of biogas process. In Science of the Total Environment, vol. 463, pp. 541-551.

BERBERICH, M. E. - BEAULIEU, J. J. - HAMILTON, T. L. - WALDO, S. BUFFAM, I. 2019. Spatial variability of sediment methane production and methanogen communities within an eutrophic reservoir: Importance of organic matter source and quantity. In Limnology and Oceanography, vol. 9999, pp. 1-23.

BUJOCZEK, G. - OLESZKIEWICZ, J. - SPARLING, R. - CENKOWSKI, S. 2000. High solid anaerobic digestion of chicken manure. In Journal of Agricultural Engineering Research, vol. 76, pp. 51-60.

CORLEY, R. H. V. 2009. How much palm oil do we need? In Environmental Science and Policy, vol. 12, pp. 134-139.

DAI, X. - DUAN, N. - DONG, B. - DAI, L. 2013. High-solids anaerobic co-digestion of sewage sludge and food waste in comparison with mono digestions: stability and performance. In Waste Management, vol. 33, pp. 308-316.

DARWIN - TRIOVANTA, U. - RINALDI, R. 2019. Two-stage anaerobic co-digestion of landfill leachate and starch wastes using anaerobic biofilm reactor for methane production. In Progress in Agricultural Engineering Sciences, vol. 15, pp. 53-70.

DARWIN - ILHAM, M. - FAZIL, A. 2018a. Performance and kinetic study of the anaerobic co-digestion of cocoa husk and digested cow manure with high organic loading rate. In INMATEH-Agricultural Engineering, vol. 55, pp. 131-140.

DARWIN - CHARLES, W. - CORD-RUWISCH, R. 2018b. Ethanol and lactic acid production from sugar and starch wastes by anaerobic acidification. In Engineering in Life Sciences, vol. 18, pp. 635-642.

DARWIN - CHENG, J. J. - LIU, Z. - GONTUPIL, J. 2016. Anaerobic codigestion of cocoa husk with digested swine manure: evaluation of biodegradation efficiency in methane productivity. In Agricultural Engineering International: The CIGR Journal, vol. 18, pp. 147-156.

DARWIN - FAZIL, A. - ILHAM, M. - SARBAINI - PURWANTO, S. 2017. Kinetics on anaerobic co-digestion of bagasse and digested cow manure with short hydraulic retention time. In Research in Agricultural Engineering Journal, vol. 63, pp. 121-127.

DINÇER, I. - ZAMFIRESCU, C. 2014. Advanced power generation systems. In Academic Press, pp. 129-133.

GONTUPIL, J. - DARWIN - LIU, Z. - CHENG, J. J. - CHEN, H. 2012 Anaerobic co-digestion of swine manure and corn stover for biogas production. In Annual International Meeting Conference, American Society of Agricultural and Biological Engineers, July 29-August 1, 2012, Dallas, U.S.A.

HALLAJI, S. M. - KUROSHKARIM, M. - MOUSSAVI, S. P. 2019 Enhancing methane production using anaerobic co-digestion of waste activated sludge with combined fruit waste and cheese whey. In BMC biotechnology, vol. 19, pp. 19.

HELLER, K. J. 2001. Probiotic bacteria in fermented foods: product characteristics and starter organisms. In The American Journal of Clinical Nutrition, vol. 73, pp. 374-379.

JIANG, J. - ZHANG, Y. - LI, K. - WANG, Q. - GONG, C. - LI, M. 2013. Volatile fatty acids production from food waste: effects of $\mathrm{pH}$ temperature, and organic loading rate. In Bioresource Technology, vol. 143, pp. 525-530.

KOLTER, R. - SIEGELE, D. A. - TORMO, A. 1992. The stationary phase of the bacterial life cycle. In Annual Review of Microbiology, vol. 47, pp. 855-874.

LANA, R. P. - RUSSELL, J. B. - VAN AMBURGH, M. E. 1998. The role of $\mathrm{pH}$ in regulating ruminal methane and ammonia production. In Journal of Animal Science, vol. 76, pp. 2190-2196.

LIU, X. - BAYARD, R. - BENBELKACEM, H. - BUFFIÈRE, P. - GOURDON, R. 2015. Evaluation of the correlations between biodegradability of lignocellulosic feedstocks in anaerobic digestion process and their biochemical characteristics. In Biomass and Bioenergy, vol. 81, pp. 534-543.
LIU, C. F. - YUAN, X. Z. - ZENG, G. M. - LI, W. W. - LI, J. 2008. Prediction of methane yield at optimum $\mathrm{pH}$ for anaerobic digestion of organic fraction of municipal solid waste. In Bioresource Technology, vol. 99, pp. 882-888.

NAIK, L. - GEBREEGZIABHER, Z. - TUMWESIGE, V. - BALANA, B. B. MWIRIGI, J. - AUSTIN, G. 2014. Factors determining the stability and productivity of small scale anaerobic digesters. In Biomass and Bioenergy, vol. 70, pp. 51-57.

NASIR, I. M. - GHAZI, T. I. M. - OMAR, R. 2012. Production of biogas from solid organic wastes through anaerobic digestion: a review. In Applied Microbiology and Biotechnology, vol. 95, pp. 321-329.

NIEVES, D. C. - KARIMI, K. - HORVÁTH, I. S. 2011. Improvement of biogas production from oil palm empty fruit bunches (OPEFB). In Industrial Crops and Products, vol. 34, pp. 1097-1101.

RAHIMI-AJDADI, F. - ESMAILI, M. 2020. Effective pre-treatments for enhancement of biodegradation of agricultural lignocellulosic wastes in anaerobic digestion-a review. In Acta Technologica Agriculturae, vol. 23, no. 3, pp. 105-110.

RALLU, F. - GRUSS, A. - MAGUIN, E. 1996. Lactococcus lactis and stress. In Antonie van Leeuwenhoek, vol. 70, pp. 243-251.

RICE, E. W. - BAIRD, R. B. - EATON, A. D. 2017. Standard Methods for the Examination of Water and Wastewater. 23rd edition. In American Public Health Association, Washington, D.C., U.S.A. ISBN 9780875532875.

UDDIN, W. - KHAN, B. - SHAUKAT, N. - MAJID, M. - MUJTABA, G. MEHMOOD A. - ALI, S. M. - YOUNAS, U. - ANWAR, M. - ALMESHAL, A. M. 2016. Biogas potential for electric power generation in Pakistan: A survey. In Renewable and Sustainable Energy Reviews, vol. 54, pp. 25-33.

USDA. 2007. Indonesia: Palm Oil Production Prospects Continue to Grow, Foreign Agricultural Service. Commodity Intelligence Report. In The United States Department of Agriculture.

VEEKEN, A. - KALYUZHNYI, S. - SCHARFF, H. - HAMELERS, B. 2000. Effect of $\mathrm{pH}$ and VFA on hydrolysis of organic solid waste. In Journal of Environmental Engineering, vol. 126, pp. 1076-1081.

WALTER, A. - FRANKE-WHITTLE, I. H. - WAGNER, A. O. - INSAM, H. 2009. Methane yields and methanogenic community changes during co-fermentation of cattle slurry with empty fruit bunches of oil palm. In Bioresource Technology, vol. 175, pp. 619-623.

WANG, D. - Al, J. - SHEN, F. - YANG, G. - ZHANG, Y. - DENG, S. ZHANG, J. - ZENG, Z. - SONG, C. 2014. Improving anaerobic digestion of easy-acidification substrates by promoting buffering capacity using biochar derived from vermicompost. In Bioresource Technology, vol. 227, pp. 286-296.

XU, Z. - ZHAO, M. - MIAO, H. - HUANG, Z. - GAO, S. - RUAN, W. 2014. In situ volatile fatty acids influence biogas generation from kitchen wastes by anaerobic digestion. In Bioresource Technology, vol. 163, pp. 186-192.

YU, B. - LOU, Z. - ZHANG, D. - SHAN, A. - YUAN, H. - ZHU, N. ZHANG, K. 2015. Variations of organic matters and microbial community in thermophilic anaerobic digestion of waste activated sludge with the addition of ferric salts. In Bioresource Technology, vol. 179, pp. 291-298.

YE, R. - JIN, Q. - BOHANNAN, B. - KELLER, J. K. - MCALLISTER, S. A. - BRIDGHAM, S. D. 2012. $\mathrm{pH}$ controls over anaerobic carbon mineralization, the efficiency of methane production, and methanogenic pathways in peatlands across an ombrotrophicminerotrophic gradient. In Soil Biology and Biochemistry, vol. 54, pp. 36-47.

ZHU, J. - WAN, C. - LI, Y. 2010. Enhanced solid-state anaerobic digestion of corn stover by alkaline pretreatment. In Bioresource Technology, vol. 101, pp. 7523-7528. 